\title{
On the History of the Form of Administrative Decisions How Decisions Begin to Desire Uncertainty
}

\author{
Åkerstrøm Andersen, Niels; Pors, Justine Grønbæk
}

Document Version

Accepted author manuscript

Published in:

Management \& Organizational History

DOI:

10.1080/17449359.2017.1324800

Publication date:

2017

License

Unspecified

Citation for published version (APA):

Akerstrøm Andersen, N., \& Pors, J. G. (2017). On the History of the Form of Administrative Decisions: How Decisions Begin to Desire Uncertainty. Management \& Organizational History, 12(2), 119-141.

https://doi.org/10.1080/17449359.2017.1324800

Link to publication in CBS Research Portal

\section{General rights}

Copyright and moral rights for the publications made accessible in the public portal are retained by the authors and/or other copyright owners and it is a condition of accessing publications that users recognise and abide by the legal requirements associated with these rights.

Take down policy

If you believe that this document breaches copyright please contact us (research.lib@cbs.dk) providing details, and we will remove access to the work immediately and investigate your claim. 


\section{On the History of the Form of Administrative Decisions: How Decisions Begin to Desire Uncertainty}

\section{Niels Akerstrem Andersen and Justine Gronbæk Pors}

Journal article (Accepted version)

Cite: On the History of the Form of Administrative Decisions : How Decisions Begin to Desire Uncertainty. / Akerstrom Andersen, Niels; Pors, Justine Gronbæk. In: Management \& Organizational History, Vol. 12, No. 2, 2017, p. 119-141.

This is an Accepted Manuscript of an article published by Taylor \& Francis in Management \& Organizational History on 16 May २017, available online: http://www.tandfonline.com/10.1080/174449359.2017.1324800 


\section{On the History of the Form of administrative Decisions: How Decisions begin to desire Uncertainty}

\section{Niels Åkerstrøm Andersen \& Justine Grønbæk Pors}

\section{Introduction}

In the literature on the history of organization, one can sometimes get the impression that it is only the context and technologies of decisions that have a history, not the operation and phenomenon of the decision itself. Decisions and individual choices are often understood to be interchangeable. Sometimes decisions are defined simply as a choice among alternatives. It is presumed that it is individuals who choose and make decisions, and that decisions make the future. A history of decisions then becomes a history of the conditions of individual choices as in Murat Köksalan, Jyrki Wallenius and Stanley Zionts' study of the history of multiple criteria decision-making. They look at how individuals come to make a decision. For example, they found it interesting how Benjamin Franklin decided his position on important issues by writing arguments in favor of an issue on one side of a sheet of a paper, and arguments against on the other side (Köksalan, Wallenius, and Zionts $2013,88)$. Such an observation puts the phenomenon of decision outside history, or as they say “The practice of decision-making is as old as man" (Köksalan, Wallenius, and Zionts 2013, 87).

The aim of this article is to make the form of decision-making itself an object of exploration and to investigate the transformation of the form of administrative decisions in the history of the Danish public sector. Beginning in the constitution of the formal bureaucracy in the late nineteenth century and following the transformation of the decision until today, we depict how new forms of decisions, capable of dealing with more and more complexity, emerge. We show how public administration becomes a differentiated autopoietic machine, simultaneously producing and cancelling its own 
decisions, counter-intuitively stabilizing itself by making it increasingly difficult to reduce uncertainty.

As a central topic in organizational science, decision-making was first and foremost developed by Herbert Simon, James March and Richard Cyert from the end of the 1950s (Simon 1959, 1961, 1964; Lindblom 1959; Cyert, Simon, and Trow 1956; Cyert and March 1963). For them, the concept served the function of opening up the organization from the black box it was assumed to be in economic theory. Though their aim was to bring in the 'social' dimension, decisions were basically seen as individual choices. For Simon, the organization consists of staff members. Staff members are observed as decision makers. A decision is defined as "drawing conclusions from premises" (Simon 1961, xii). Therefore, the focus is not so much on the decisions as on the making of premises. Whereas decisions are observed as a result of individual choices, decision premises are the result of complex organizational processes, and, in every decision, a large number of premises are combined. This leads Simon to conclude, "A complex decision is like a great river, drawing from its many tributaries the innumerable component premises of which it is constituted" (Simon 1961, xii).

We might say that in the framework proposed by Simon, decision-making is split into a psychological part and a social part. The decision in itself is psychological, and the making of premises is social. In this article, we argue that in order to study the history of 'administrative decision-making' it is insufficient to assume that individual choice and decision are the same, and it seems strange to keep half of the distinction between decision and premises outside history as a kind of universal psychological constant. We need to understand the decision not as a psychological operation, but as the basic operation of any organization fulfilling a particular function, that in no way can be reduced to individual choice. We do not deny the importance of individual choices, but we observe individual choices and organizational decisions as different phenomena and operations 
that cannot be reduced to one another. We therefore choose to follow Niklas Luhmann's systems theory and his suggestion to observe organizations stringently as social communication (for this tradition see Luhmann 1964, 1993, 2000; Nassehi 2005; Knudsen 2005; Schoeneborn, Blaschke, Cooren, McPhee, Seidl, and Taylor 2014; Esposito 2013; Blaschke, Schoeneborn, and Seidl 2012).

Following this tradition, we see decisions as organizational communication. Indeed, we conceive of organizations as nothing but decision communication including references to former decisions (decision premises). Decisions function to absorb uncertainty in the organization not by determining the future, but by attuning the multiple expectations that always flow between the members of an organization about the organization's future, their respective roles and, not least, what to expect of future decisions. Decisions are recursive; it takes a new decision to decide whether a former decision is a decision or just loose talk. The decision to observe a former decision as a decision transforms the former decision into a decision premises. Premises are not built up before decisions. Decisions recursively construct their own premises. To study the history of administrative decisions in the public sector we therefore need to study how the distinction between premises and decisions are drawn recursively in decision-making over time. How are decisions observed and conceptually framed in the organizational communication? What makes a decision a decision at different points in time?

Thus, this article aims to make the form of decision-making an object of exploration and to investigate the transformation of the form of administrative decisions in the history of the Danish public sector. We will investigate how different forms of decisions emerge over time, each with very different capabilities of handling complexity. We will show how different forms of decision operations come to co-exist in the public administration today. And, finally, this will also help us to demonstrate how decisions are not just made in time, but are communicative operations that produce particular temporalities. 
The article proceeds as follows. First, we elaborate our conceptual framework of decisions as a particular kind of communication. Second, we present the data and our methodology. Third, we present our analysis of the history of the administrative decision. We identify four different forms of decisions each emerging at a particular point in time. Finally, we offer a conclusion.

\section{Conceptual framework}

According to Luhmann $(2000,1993)$, decisions are communicative operations that draw a distinction indicating that we are now past the decision. 'Before', therefore, always appears in the order of the 'after' of the decision. From the perspective of the decision, the 'before the decision' appears as the space of open contingency regarding expectations. The decision's 'before' is a moment when a specific situation still had many conceivable outcomes, a moment when much could still be changed. After the decision, this contingency, this openness with respect to the outcome, appears in a fixed form, that is, as the notion that the decision could have been made differently. Only one outcome was chosen, but other outcomes could have been chosen. What might have been different has now been determined. We could have done something, but we did something else. Thus, in every operation, decision communication forms the distinction fixed/open contingency with respect to social expectations (Luhmann 1993).

Decision communication functions to absorb uncertainty in the organization, and fixes and attunes expectations. However, new uncertainty is simultaneously produced. It becomes apparent that the decision could have been made differently. Furthermore, new decisions are potentialized at the moment a decision is made. This means that a decision produces new possible connections for future communication. 
Thus, decision communication is linked to complexity. In systems theory complexity is always a self-conditioning state (Luhmann 1995, 23-27). A system is complex when there are more potential relations between the elements of the system than the system is able to actualize. This creates complexity as an inevitable condition forcing the system to select. Regarding decisions the question become how different forms for decisions deals with the problem of selection and as an effect produce different forms of self-conditioned complexity.

Decisions use time, but they also create their own temporality, partly because every decision operation draws distinctions between before and after the decision, and also because temporal differences are used to turn decisions into decision premises: that is to mark something as either not changeable or a contingent premise. To follow this more concretely we have to look at the temporal semantic and how it changes over time (Andersen 2011a; Luhmann 1982), that is, how distinctions between past, present, and future change over time with consequences for the form of the decision operation.

Thus, this conceptual framework provides us with the possibility of observing decisions, not as individual choices, but as decision communication. We will study how social contingency is fixed in decision communication by the drawing of certain distinctions. Also, this framework makes it possible to be investigate, not simply decision processes, but changes of the communicative forms that decisions take over time in public administration. By form we mean the unity of a distinction drawn by the communication (Spencer Brown 1969).

\section{Data and methodology}

Empirically, this article draws together a number of studies we have conducted on the history of the Danish public sector from 1880 until today. Previously, we have studied the history of Danish administrative policies since 1860 with a point of departure in an archive consisting of all 
commissions' reports as well as policy documents (Andersen 1995, 2005; Andersen and Born 2000;). We have examined the history of certain ministries (The Ministry of Labor, The Ministry of Environment, The Ministry of Trade and Industry, and the Ministry of Finance) from their formal constitution (Andersen 1995; see also Jensen 2003, 2008, 2012), and traced the semantic history of the public employee from 1840 until today (Andersen and Born 2001; Andersen 2013; Andersen and Pors 2014a). In addition, we have scrutinized the history of the relation between central government, local authorities and individual welfare organizations (Andersen and Pors 2016), particularly within the field of education (Pors 2011). Finally, we have studied the history of the client in social policy (Andersen 2003, 2007).

In this article, we conduct a cross reading of all these studies, focusing solely on the operation of the administrative decision. Our guiding question is how the form of an administrative decision changes in public administration over time. Our methodology can be summarized as an attempt to trace the semantic history of decision communication (Andersen 2011; Stäheli 2003; Rennison 2007). Drawing on Reinhart Koselleck, Luhmann defines semantics as certain structures that "hold ready forms of meaning that communication treats as worth preserving" (Luhmann 2000, 331, 205). To study semantics means to study how a stock of generalized forms are created, and how they form a horizon of meaning that can be used in communication to manage expectations (Henkel 2013). In this study, this means that we examine the development and transformations over time of the semantic structures that make it possible for the Danish public administration to communicate certain expectations to decision-making.

It is important to stress that this is not a study about how the Danish public administration has been influenced by international policy movement. Of course, the Danish public administration is not an isolated island, and over time, it has been influenced by different policy movements particularly in France, Germany and England. However, to map these influences is beyond the scope of this 
article. Also, this has been scrutinized elsewhere (e.g. Greve 2006; Campbell and Pedersen 2014). Here, our focus is limited to the development of the form of decision communication.

To bring order to a wealth of data sources, we depict the development through four main transitions of the form of the decision: in our words, from administrative decision, to planning, to strategy, to potentialization., As Koselleck has argued, it is the conduct of framing historical periods that opens up a field to a particular inquiry (Costea, Crump, and Holm 2006, 165). In this paper, the periodization reflects our interest in the changing forms of decision communication. Another point of observation might lead to different periodization. It is important to note that the development is cumulative. Sector administration adds itself as principle to bureaucratic administration, and supervision administration adds itself to sector administration without causing the previous order of administration to disappear. Our argument does not involve a claim of separate periods replacing each other, but rather a claim of growing forms of complexity resulting in many simultaneous orders of decision making, where every order has its own 'ordering' and understanding of what makes a decision. All four forms of administration coexist today, sometimes harmoniously and at other times in competition or conflict.

\section{Bureaucracy: The constitution of the administrative decision}

Our starting point is formal bureaucracy based on the idea of the constitutional state. Formal bureaucracy was in the making at least from the middle of seventeen century. However, we begin our study when it already is a fact, and when it begins to reflect upon itself as a legal State (Recht Stat) from the mid- and late-1800s. We can trace the gradual development of formal bureaucracy, a division into different offices for different jurisdictions and administrative responsibilities. As we know from Max Weber, formal bureaucracy can be described by a number of characteristics: First 
of all "There is the principle of official jurisdictional areas, which are generally ordered by rules, that is by laws or administrative regulation" (Weber 1978, 956). His second characteristic is "The principles of office hierarchy (...) in which there is a supervision of the lower offices by higher ones" (Weber 1978, 957). This means that the source of authority is based on delegation (Mommsen 1974, 76). Weber attributes to the formal bureaucracy technical qualities such as "precision, speed, unambiguity, knowledge of the files, discretion, unity, strict subordination, reduction of friction and of material and personal cost" (Weber 1978, 973). In summary, he thinks that bureaucratization "offers above all the optimum possibilities for carrying through the principle of specializing administrative functions according to purely objective considerations" (Weber 1978, 975). Or as Wolfgang Mommsen articulates it: "Bureaucracy of necessity recognizes everything it comes into contact with according to strictly 'instrumental-rational' principles (Mommsen 1974, 64).

In Denmark, formal bureaucracy begins around 1870 when the first teaching book tries to conceptualize and separate administrative law as an autonomous area within State law. The author of the book, Carl Georg Holck argues that: "The function of administrative law is to express the work of the State related to its different purposes. Administrative law in other words expresses the State at work, while constitutional law expresses the State at rest" (Holck 1870, 2). In 1893, the first Danish doctoral thesis on administrative law is published. Johannes Ussing draws a distinction between a legal state and a police state, and argues that law is founded in the citizens' private sphere of law that is to be considered as inviolable (Ussing 1893, 3). However, it is on Poul Andersen's doctoral thesis on invalid reasons within administrative law that Danish administrative law and formal bureaucracy are truly founded. The thesis connects to the code of law (legal/illegal), and indicates the reflexive side of the code (illegal) examining the condition under which the practice of the public administrative becomes juridical invalid (Andersen 1924). 
The development of formal bureaucracy in the public sector is conditioned by a stronger legal basis for administrative activities, including an unambiguous legal constitution of its practice in the form of administrative records. The development and differentiation of the semantic of administrative law is a foundation for formal bureaucracy in the public sector, where administrative law is basically understood as the description of the activities of the state with respect to the different functions of the state, and a doctrine of the order of the executive power and its activities with respect to the different functions of the state (Ross 1959).

Defining the decision operation of bureaucracy was one of the largest issues articulated in administration law up to the Second World War. It was named the administrative decision, and in Danish administrative law it was defined as: "a unilateral statement by an administrative body of specific and legally binding content" (Andersen 1926, 22ff, Andersen 1946, Christensen 1980, 1622). This is what public administration does. It makes unilateral decisions, which are binding for the involved parties without the parties' involvement in the decision. Unilateral means that the administration holds the sovereign power of decision. It requires neither consent nor agreement from hierarchically subordinate parties, e.g. a citizen or business affected by the decision. Thus, the concept of the administrative decision is defined in contrast to the contract as counter concept defined as a mutual statement. As a mutual statement between parties, a contract is not valid until the parties agree on the relationship of obligations to which they subject themselves. A contract represents a voluntary restriction of one's freedom. Thus, the constitutional basis of administrative law specifically excludes the contract. And this marks a line between two different legal standards: administrative law and civil law. It also marks a legal division of society into state and society. Whereas a contract represents a mutual statement between equal parties, an administrative measure represents a unilateral statement within a hierarchical leader-subordinate relation. In the semantic of 
administrative law the administration is defined as a hierarchy within which power can be legally exercised in the form of administrative measures in accordance with specific rules.

Administrative decisions are about legal cases, and they connect to earlier administrative decisions as premises, constituted as legal facts. As an effect, the formal bureaucracy can be described as a case management machine with carefully defined areas of responsibility and guidelines for case management, as well as clearly defined areas of competence and archiving methods. These factors ensured both a certain level of external control of case management and knowledge accumulation, as well as the development of a predictable case management practice through ongoing comparisons of current cases with decisions arrived at in previous similar cases.

The formal bureaucracy and its unilateral administrative decisions draw on a particular temporal semantic. As administrative decisions focused on the past (as seen from the present), administrative decisions were based on previous decisions. Administrative decisions referenced previous decisions, which made for a relatively predictable form of case management. In this scenario, the future remains merely an externality, which an administrative decision is unable to account for or relate to. Hence the future was not a decisive factor, neither in the self-description of the bureaucracy nor as a reference for decisions. A decision established a past of previous cases relevant to a particular case, and the future was externalized as those things about which decisions could not be made. Thus, the formal bureaucracy operated communicatively with a present's past. The case orientation also affects the whole self-description and the internal differentiation in public administration. In a formal bureaucracy, governing means controlling administrative measures and the objects of governance, i.e. individual offices and officials. The condition of governing and control is the self-discipline of individual officials. Thus, even though formal bureaucracy can be described as chains of power relations and hierarchical subordination, the premise of governing 
remains self-governing throughout. But self-governing takes a particular form in formal bureaucracy: as self-discipline. Thus, any power's capacity limit is established through the ability of individual officials to independently act in a systematic, consistent and disciplined way while referring upward in the hierarchy regarding definition of cases, objectives, decision-making procedures, legal basis, etc. (Condren 2006). In that way, the biggest challenge of administering the formal bureaucracy is the minimization of the distinction between rules on the one hand and the practices of administration officials on the other, and to ensure that such practices reflect the rules. As part of that effort, public administration can refer to itself as a hierarchy and as a hierarchy of hierarchies.

The fundamental bureaucratic paradox is that this system has to apply general rules to all specific cases and unique situations. Because bureaucracy operates by means of rules, its only response to individual cases is to generalize, universalize and formalize.

As we will pursue below, as the formal bureaucracy develops and grows, this bureaucratic paradox becomes increasingly problematic. How can the system act when reality is changing faster than the rules are able to adapt? How can the system act when rules develop, expand and become confusing and perhaps even contradict each other? How does the system act when the complexity of the law no longer corresponds to the complexity of society? Internal complexity gradually grows to the point that it can no longer be formalized away.

\section{Sector administration: Planning as a decision of second order}

Responding to the difficulty of handling complexity within public administration and forging greater compatibility between the speed of change in public administration and society, an ideal form of administration emerges in the late 1950s and is slowly institutionalized in the 1960s and 
1970s. This change is initiated by repeated experiences of being out of sync in law reforms. In a formal bureaucracy, change often involves change of law, and following democratic legal procedures takes a lot of time. The process might begin by setting up a policy commission that is to analyze a problem and produce a report. Then a civil servant in central government has to formulate suggestions for a new law. There is then discussion in parliament that might lead to a new law that finally has to be implemented. It is articulated as a problem that updating the legal basis for individual programs cannot solve adaptations, because such adaptations become obsolete before they can begin to take effect (Teknikerkommissionen 1959). Instead, hope is invested in an administrative reform designed to ensure ongoing coordination and planning of individual programs on the basis of a comprehensive sectorial perspective. The semantic ideal is a coherent coordination of all parts of public administration. The central question is how to create coordination among sectors and handle the new internally produced complexity within public administration (Administrationsudvalget af 1960, 1962a).

At the time, the arguments for reforming a formal organized administrative area into planning sectors often used a particular narrative for framing the problem. This semantic narrative has four steps: 1. Originally, there was administrative unity and a clear and unambiguous hierarchy of rules. 2. Developments leading to greater administrative scope and complexity have resulted in administrative divisions. 3. Thus, unity is lost and is replaced by imbalances and coordination problems. And 4. Unity is to be restored through planning and the coordination of public administration into sectors (Administrationsudvalget af 1960, 1962b, 1964, 1965, 1966).

The result is a split of the form of decision into first and second order. First order continues as the unilateral administrative decision, and, as a kind of second order supplement, planning emerges. Planning can be described as second-order administrative decisions. Planning is decisions about premises for subsequent administrative decisions (Luhmann 1971). Where administrative decisions 
try to absorb uncertainty regarding behavioral expectations, planning communication tries to absorb uncertainty regarding expectations to goals and problems. Planning does not orient itself directly toward the individual case, but focus on broader issues whose definition and prioritization establish premises for subsequent case management.

The focus on planning meant that the future was described as calculable. Public councils and commissions identified specific developments in the world and prescribed reforms designed to ensure that administrative units and policies adapted to the new conditions. The public sector was guided by the belief that the world was moving in one particular direction and that its job was to adapt to this movement. The present was a question of analyzing the past as a means to determine the future and conduct the appropriate planning. In this way, planning was about constructing the future as a decision premise for present decisions. This involves a presentification of the future, which brings the calculation of the future into the present, deciding to treat it as a premise of the present. Planning, thus, entailed a temporal semantic of the future of the present.

Public administration becomes organized into separate sectors and the central administration develops its planning capacity. Many rules are combined into so-called framework laws, and the various sectors are given planning authority. Whereas formal administration was hierarchically divided into offices with clearly delimited legal competencies designed to make decisions about particular types of cases, the new vertical sectors are defined instead as different policy areas such as education, workplace environment, labor market, and taxation. Each sector is organized around a particular set of government problems so that a sector represents a problem-driven administrative pillar. The sectors do not make decisions about cases but establish premises for subsequent casemanagement by defining and prioritizing problems. They operate as a planning superstructure added to a formal administration. 
The problem, however, is that the administration's sectorization produces its own complexity and generates new forms of public administration unmanageability. The intention behind the sector organization was to solve the problem of growing complexity and unmanageability caused by years of administrative expansion. Planning was intended to ensure vertical coordination within a sector, so that, for example, all educational activities in the education sector were coordinated through educational planning that reflected analyses of educational needs in a society. The idea was that the position at the top of the vertical government chain would enable a holistic perspective, which is why planning competences would be located there. However, as the sectors develop and multiply, a certain "sector egotism" emerged. Individual sectors only concerned themselves with their specific areas of interest and expertise. The sector of environmental policies, for instance, focused solely on environmental issues and was unable to see how some of its measures might solve problems in the environment, but simultaneously created new problems for the labor market. Also individual sectors tended to constantly discover new needs, and hence to demand increased resources. Such demands produced a growth in the public sector, which in turn causes socio-economic balancing difficulties. New types of plans emerged articulating horizontal coordination problems across the sectors. These were called "Perspective plans" and have a 15-year timespan. The first one was published in 1971 (Arbejdsministeriet 1971), covered 1970-1985 and pointed to a growing imbalance between the public and the private sector. The public sector is said to push out the private sector. Perspective Plan no. 2 repeated and radicalized this problem saying that the public sector absorbs too large a part of the highly-skilled labor force, weakening the economic export sector with serious consequences for the Danish economy (Arbejdsministeriet 1973). Thus, the Danish economy was constructed as the "whole" of "wholes", wherein all parts of the public sector (the sectors and all their activities) should be coordinated. It becomes increasingly clear that the sector-based vertical 
mode of planning had to be supplemented by horizontal planning, including horizontal expense policies. Thus, planning breeded more planning.

This way of thinking peaked in the mid-1970s with Report 743 from 1975 representing the culmination of Danish planning optimism (Udvalget vedr. Centraladministrationens planlægningsvirksomhed 1975). The complexity of the intended planning system appears clearly in the figure 1. The ambition was "comprehensive and general planning which would provide a framework for more concrete and specialized planning." (Udvalget vedr. Centraladministrationens planlægningsvirksomhed 1975, 56). However, the commission did not consider it possible "to develop one comprehensive plan for the growth of the entire Danish society." (Udvalget vedr. Centraladministrationens planlægningsvirksomhed 1975,57 ) The idea was a state composed of a range of sectors that corresponded to different problem areas such as vocational training, universities, working environment, and pollution. The sectors would develop 5-year vertical plans, i.e. plans within the sector pillar. In addition to the sectorial planning system, four planning centers would be constructed and operate as superstructures for the planning of the sectors' planning. Such centers would develop 10-year horizontal plans. One would be a center for expense policies; another center would be for infrastructure. Above the four planning centers would be yet another central planning center, which would plan the planning of the planning centers in 15-year increments. One such center became a reality with The Budget Department, and the Ministry of Finance remains to this day the most planning-enthusiastic institution in Denmark. 


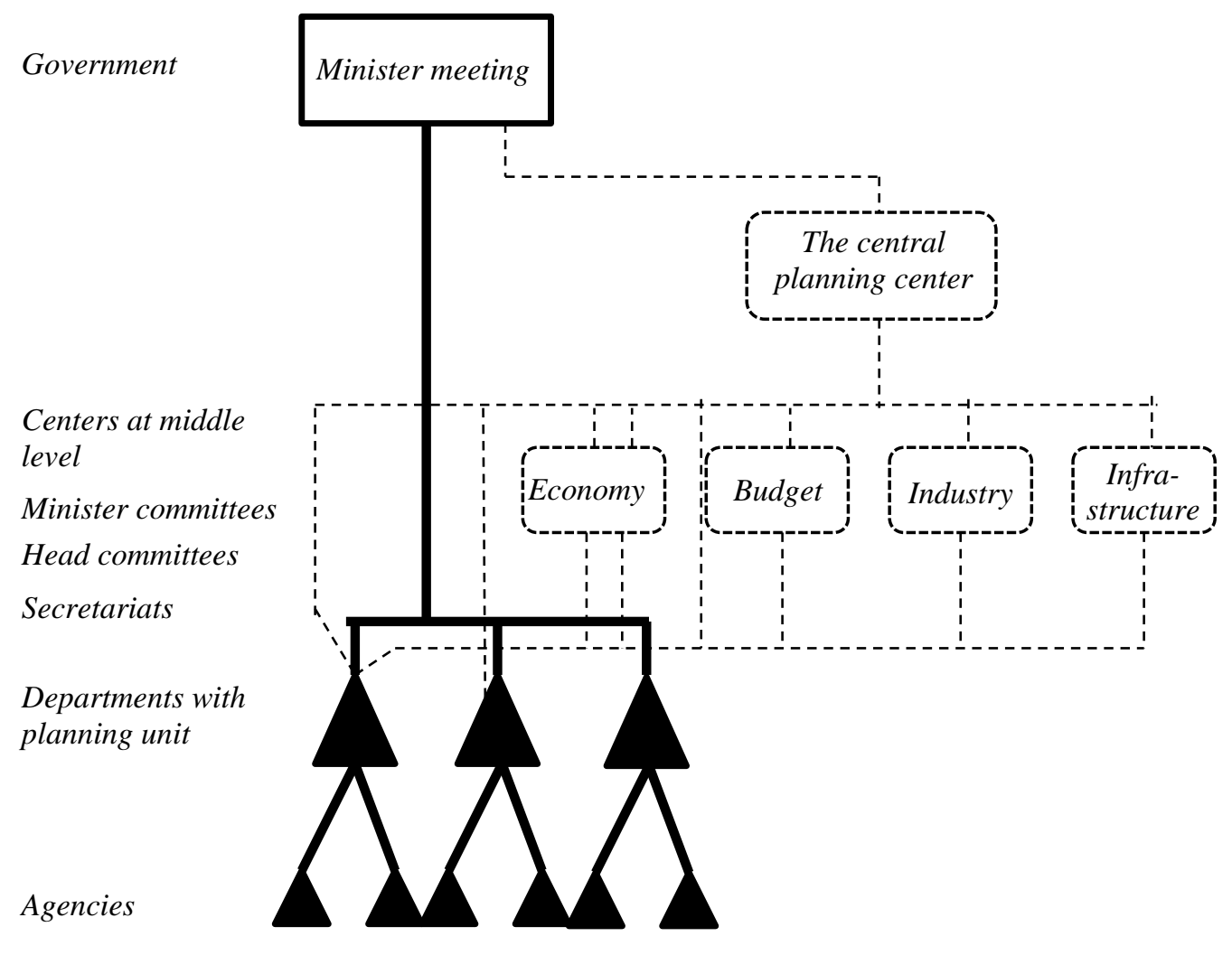

Figure 1: Report 743 about central administration planning (re-making from Udvalget vedr.

Centraladministrationens planlægningsvirksomhed 1975)

The consequence of these developments is a semantic of planning of planning of planning, and in the 1970s, the planning discourse reached its evolutionary limit. It transpired that planning simply led to more planning, which increased complexity and produced a lack of methodology in the public administration.

\section{Supervision administration: Strategy as decisions of a third order}

The unlimited faith in planning finally broke down from the late 1970s, and New Public Management emerged as the new discourse (du Gay 2007, 375; Corby 1993; Freedland 1994, 
Vincent-Jones 2007; Vincent-Jones, Hughes and Mullen 2009, Campbell 2007; Bogdanor 2001). It became increasingly difficult to collect and process the information necessary to maintain planning systems, and gradually we see the popularization of rewards systems for departments that actively subscribe to adaptability rather than departments that passively subscribe to prevention with regards to expense management.

In Denmark, the semantic rupture happened in 1980. At a conference for Danish economists, Inge Thygesen, a leading civil servant, articulated a new idea of decentralizing the capacity to change and adaption. Coordination should begin from the single public institution that should constantly be ready for change (Thygesen 1980). The Department of Administration followed up by arguing for the development of a new cost and economy consciousness throughout the public administration (Administrationsdepartementet 1981). The third perspective plan was published in 1983 and had the title "All that planning: how and why?" It delivered the final kiss of death to planning optimism. Instead of "formal regulation" it indicated "dialogue"; instead of full planning it indicated "themes, plans, and discourse management"; and instead of "binding frames" it emphasized "unbinding catalogues of ideas" (Planinformationsudvalget 1983). Later in 1983, a whole new policy of modernizing the public sector was published (Finansministeriet 1983).

Planning emerged in the 1960's as a second order administrative decision, looking for decision premises in the future rather than in the past. In the 1980s, strategic supervision emerged as a third order form of decision (for similar observations: Willke 1997, 1992; Kooiman 2003, 2008; Kooiman and van Vliet 2000; Crozier 2007). Both the form of administrative decision and form of planning were constituted as the unity of the difference between unilateral and mutual statements. Strategic supervision represents a form of decision operation that makes a re-entry of the distinction between unilateral and mutual in a sort of unilateral call for mutuality. Strategic supervision 
command the subordinated institution to behave as an autonomous organization, and to be their own independent decision system with responsibility for goal setting as well as budgeting.

This is a new way to deal with complexity. Rather than combining parts in a larger planned whole, strategic supervision commands lower levels to deal with their own complexity. This also includes the production of more complexity arising from how each unit independently observes and relates to expectations in its environment. Strategic supervision represents a withdrawn decision; a decision that invites the construction of local aims and purposes. Put in terms of governance, strategic supervision represents the paradoxical form of governing of self-governance (Dean 1999, 2007; Miller and Rose 1992; Pierre and Peters 2000; Rhodes 1997). Strategic supervision tries to absorb uncertainty regarding expectations about independency, but end up producing a double bind by simultaneously communicating unilateral and mutual relations.

In connection to planning, change was always observed against a background of stability. Now the only stability is observed as constant change. The discursive imperative becomes change in order to change. The consequence is that the future cannot be calculated. Presentification of the future is no longer possible. Future cannot be constructed as a present decision premise. This would also cancel the strategic supervision command "be autonomous!" Instead strategic supervision entails futurization of the present. This becomes a way of opening up the present space of decision-making for the subordinated organizations toward an open future horizon, and simultaneously controlling the way these organizations self-govern their new independency.

The shift to third order also affects the semantic self-description of public administration. In 1993, the Danish Ministry of Finance published a new report, "A New Perspective on the Public Sector", where they literally were drawing a new model for the public sector as can be seen in figure 2 . Here they wrote, "The hierarchical model which has traditionally dominated the public sector is replaced 
by a model based on dialogue between state and municipalities and between politicians and institutions. In this model, politicians no longer engage in detailed management" (Ministry of Finance 1993, 11, own translation). They draw the change of the public sector like this:

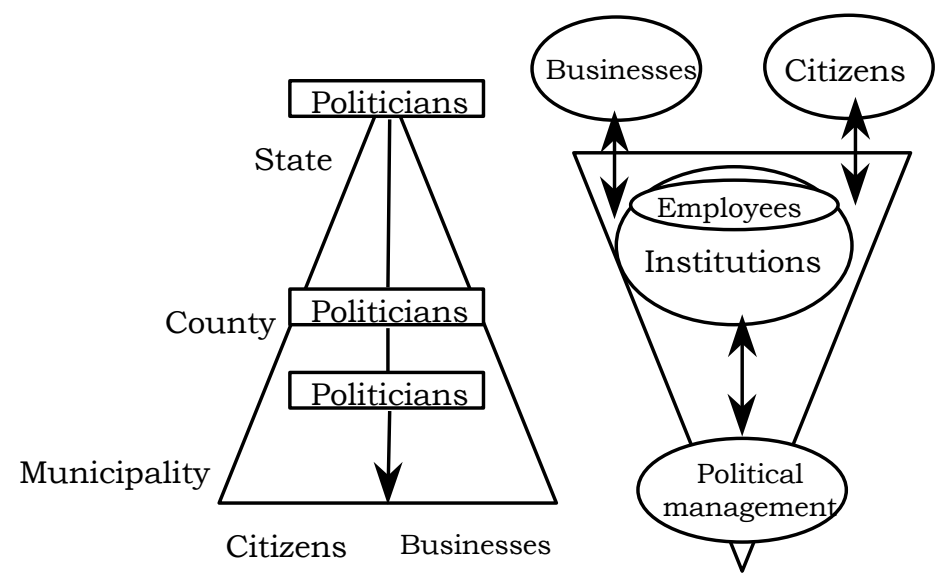

Figure 2: A new perspective on the public sector (re-making from Ministry of Finance 1993)

In this drawing by the Ministry of Finance (see figure 2) strategic supervision is articulated like this: "Governance can no longer rely on hierarchical and centralistic solutions, but has to rely on principles of dialogue and collaboration" (Ministry of Finance 1993, own translation; see also Newman 2005a, 2005b). Again we see a re-entry of the unilateral/mutual difference, here in a form of a monological call for dialogue. The same re-entry is repeated in many of the new steering technologies. An example is 'internal contracts'. These contracts are not usual contracts constituted by fully voluntary agreement as in the market. Instead they are unilateral statements demanding a mutual agreement. The internal contract becomes a steering medium used to 'autonomize' the institutions making them responsible for managing their own 'quality' and 'strategy'. Internal contracts are contracts within a hierarchy. Simultaneously they communicate: "do as I say" and "be autonomous". They are a tool for allowing greater complexity in public administration in form of institutions managing themselves and at the same time being able to claim with authority formal unity and control. Greater demands are placed on the institutions that can no longer defer responsibility with references to the political system 
(du Gay 2009, 373; Armbrüster 2005). Another example is how central evaluations of schools and other welfare institutions are supplemented with cultural forms of steering enabling the institutions to evaluate themselves. Self-assessments become a means to simultaneously govern and enhance the capacity for self-governing. As one municipality, for example, expresses it the municipality is “establishing the basis for the schools' ability to more actively document and demonstrate the quality of their teaching and pedagogical practice." (Municipality of Odense 2008) This gives the assessment reviews a dual purpose. On one hand, the reviews are meant to support and guide institutional selfgovernance, management, and strategy development, and on the other hand, they are intended to ensure administrative supervision. The evaluation reviews facilitate mutual dialogue and debate, and also serve as an avenue for the municipal administration to gain insight into potential difficulties within the institutions so that the administration can take appropriate action if necessary. The reviews constitute a hierarchical governance relation between municipal administration and institution as well as institutional self-governance (Pors 2011b). A third example is how budget policy is changed. Now all institutions are given their own budget and certain economic freedom. They are expected to act as if they were economic actors. A fourth and final example is how the concept of 'manager' is imported from the private sector in order to build up the illusion that the public institution in the hierarchy is independent representing its own wholeness. We have tried to illustrate these changes in the unity of the administration in figure 3 : 


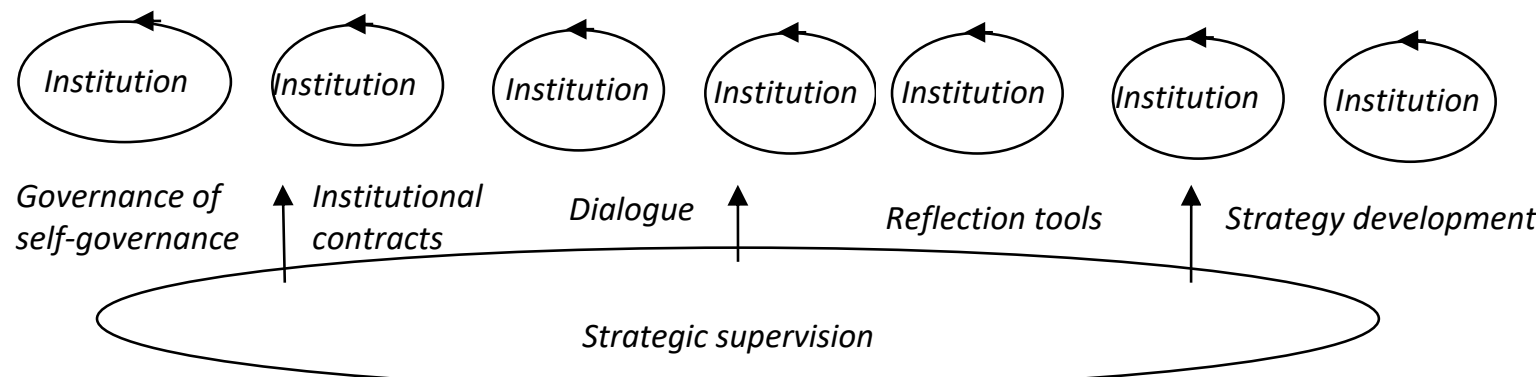

Figure 3: Supervision administration as self-description. (our own figure)

Planning emerged semantically as an answer to a complexity produced by growing bureaucracy. It was expected that planning reduced complexity, but it turned out that planning in fact produced new complexity. Strategic supervision emerged as an answer to this problem. A form of governing was introduced that loosened the connection between decisions and decision premises, thus offering premises that do not fix contingency and absorb uncertainty too much, but instead open up a horizon for local self-governance. This produced even more complexity and injects a number of new paradoxes into the public sector, reproduced again and again as different versions of "Do as we say -Be autonomous".

\section{Potentiality-seeking administration}

In the same way that the hierarchy became the source of its own complexity and that planningbased sector administration sought to respond to this complexity, and in the same way that planning did not simply solve the problem of complexity, but also produced new complexity and hence new unmanageability, the supervision administration and its emphasis on strategy building on all levels also produced new forms of unmanageable complexity. But this time complexity and the reduction 
of complexity are not articulated as simple counter-concepts. The problem of growing complexity and ungovernability is actually articulated as a problem of too little complexity at the local institutional level. Central administrations both in the state and in the municipalities observe a difference between the large complexities they themselves are aware of and the too simplified complexity the institutions observe and deal with. The problem becomes: How it is possible from the central level to increase the complexity observed by institutions in order to increase the collected administrative system's capacity of governance.

From around 2000 and onwards, a new semantic with new concepts and buzzwords enter the scene. Among them are "Radical innovation", "Re-thinking", "Thinking out of the box", and "Cocreation". These concepts are not simply about organizational change but represent a new imperative demanding that all public organizations should question themselves and their core operations. In 2006, the government released the first of a number of reports pointing at a need for a quality reform in The Danish public sector. Its buzzwords are "New thinking and focus on people." Instead of framing the future as a given horizon, this conceptual framework portrays the future as full of dilemmas without answers. These are dilemmas such as "How do we get better public services without more hands?" (Regeringen 2006, 10); "Do we all need free public service - even the wealthy?" (Regeringen 2006, 12); "Who should be responsible for service to citizens parliament or local council? "(Regeringen 2006, 14);"What rights should citizens have - a certain level of service or free choice and influence? "(Regeringen 2006, 16); "Do clear targets and documentation provide better service or more bureaucracy?" The final dilemma is elaborated like this: "The purpose of performance management is to reduce the need for rule management and bureaucracy. But the result in practice might be the opposite: more bureaucracy at the expense of service to the citizens? "(Government 2006, 16). By portraying the future as indeterminate dilemmas, the public sector and its institutions and citizens are made responsible as co-producers of 
the future. The central government communicates no clear-cut solutions, nor any clear problems or future horizons but calls instead for institutions to think outside the box. They are offered indeterminate complexity and insoluble dilemmas and are expected to see these as sources of radical innovation.

In a later report the government wrote: "The public sector must be innovative (...) The institutions must have greater freedom to innovate and develop the quality with focus on the citizens '(...) The management and employees in the public sector need to work systematically with innovation and quality improvement based on the users' and the employees' actual experience with the services. The Government will promote user-driven innovation in the public sector. (Regeringen 2007, 1-4).

The result is that potentialization emerges as a form of decision of a fourth order. The administrative decision, planning, and, to a certain extent, strategic supervision all deal with reduction of complexity, absorption of uncertainty and fixation of contingency. The higher up in the order of decision we get, the more withdrawn is the stabilization of contingency, the roomier is the premises established by the decisions, the less is absorption of uncertainty and the greater is the amount of unreduced contingency pushed ahead by the decisions. However, regardless of the order of decision, all decisions concern themselves with alternatives and they all absorb uncertainty inside the administration with respect to existing expectations. The question is how to make decisions about which opportunities to realize on the basis of a horizon of alternatives. Potentialization as a decision of fourth order seems to reverse this. Potentialization is almost unrecognizable as a decision. The fourth-order decision does not simply represent an even more withdrawn form of decision. It is not simply a decision with even less definition of premises for subsequent decisions (of the third, second, or first order). It is a decision that does not want to be a decision (Andersen and Sand 2012). It is a decision that observes uncertainty as a limited resource (for equivalent observations (Esposito 2011, 2014). The more uncertainty the more potentiality of decision. It is a 
decision that seeks not to choose to realize one opportunity from a horizon of alternatives, and tries to generate a new horizon of possibility from which subsequent decisions may choose. In other words, it is a decision, which seeks to create undefined complexity from which subsequent decisions may derive. It can only do this by doubling and re-entering the difference of decision back into itself. To decide means to relate to expectations, and this applies even when the decision in question is one that seeks to dissolve premises and generate new complexity for subsequent decisions. This kind of decision, which we will refer to as a potentiality decision, still has to decide which existing structures and assumptions to dissolve in relation to a horizon of alternative structures and assumptions, which might also have been dissolved. We have tried to formalize this re-entry of the distinction in figure 4. A decision operates with the difference fixed/open contingency regarding expectation. Potentialisation re-enter this difference on the 'fixed' side of the difference and emerge as an attempt to fix a new horizon of contingency.

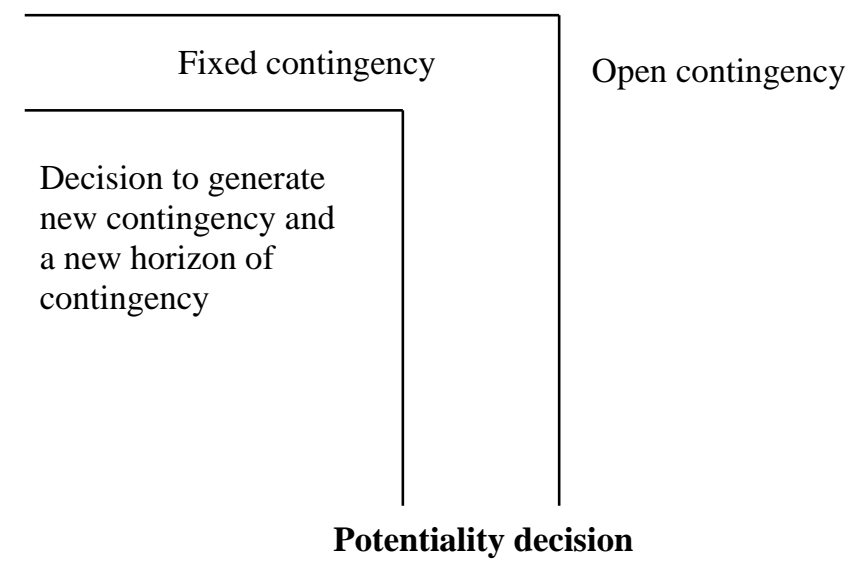

Figure 4: Potentialization as fourth-order decision (our own figure)

This decision of fourth order also performs another temporality. Remember, it is all about increasing indeterminate complexity in the lower levels by potentializing their horizons of decisionmaking. Here, present future is not good enough. There is a sense that efforts to predict the future 
say more about the present than about the future. The question is how to formulate strategies for the future based on the premise of having to expect the unexpected. The task is to establish expectations about the future with the expectation that all expectations will undergo a radical change (see Esposito 2011). The temporality is split into two disconnected ones: The future of the future where institutions should cross the present horizon of the future polluted by past and present, looking for future horizons beyond the horizon (Esposito 2011; Andersen 2013b, Andersen and Pors 2014), and the present of the present, where everything is observed as emergent singular moments, a kind of pure present. The split is an effect of observing the future as "disruption" as one of the Danish public think tanks on public innovation, MindLab, articulates it (http://mind-lab.dk/wpcontent/uploads/2015/04/mindlab_andershvid.pdf). On the one hand, MindLab articulates that the future is now and should be grasped in the pure present. On the other hand, the future is beyond our present imagination. Potentialization on the temporal dimension is about making the local institution expect the unexpected. Potentialization then is about a futurization of the future insisting on grasping the horizon beyond the horizon and thereby producing new possibilities, not yet expected, not yet imagined, not yet thinkable.

The potentiality administration does not only support self-governance through dialogue, institutional contracts, strategy training, and governance tools. The point of departure is not the preexistence of a certain amount of chaos and uncontrollability within the welfare institutions, which public administration seeks to help bring under control. By contrast, the starting point is too much order and stability. The problem is that what is uncontrollable in the institutions remains invisible to the institutions because they are locked into structures that are considered inevitable. Thus, the starting point for the central administration in the potentiality administration is that leaders do not encounter enough complexity and chaos through which to enact opportunities and change. We have tried to depict the potentiality seeking administration in figure 5. Here the central administration 
contributes to the softening of structures and the creation of new virtual possibilities for welfare institutions.

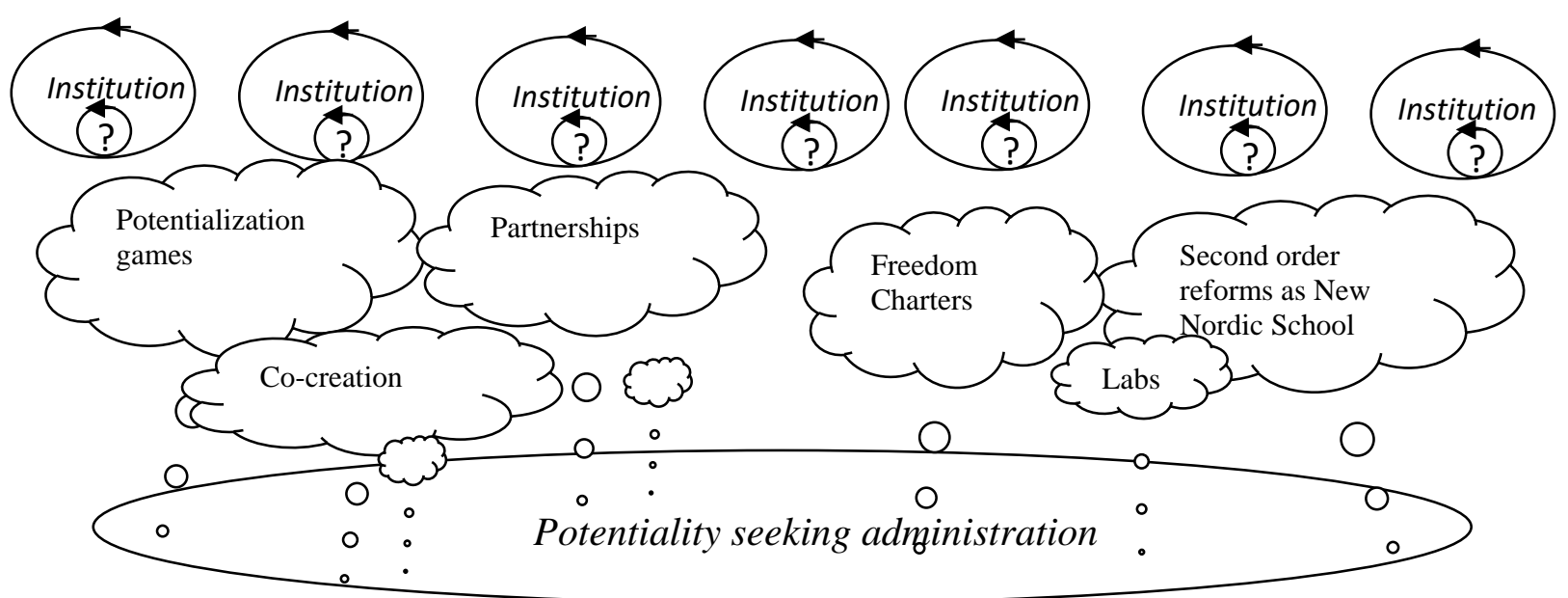

Figure 5: Potentiality seeking administration (our own figure)

The central administration provides support in the form of innovation games, future labs, freedom charters, flexible architecture, speed dating, partnership contracts, self-observation tools, responsibility games, and much more. Instead of providing answers, the central administration asks questions and instead of defining frameworks, it asks institutions to reject frameworks and question everything. In all these new steering technologies, which we might call potentialization technologies, the re-entry of the form of decision is repeated: "We fix contingent expectation expecting them to be open and unexpected". In a strange way, it is expected that new decision structures should support the de-freezing of structures.

Examples are:

Potentialization games: We can observe a large trend in using games, design methods and art in potentializing all elements in public institutions. Gregory Bateson says that play splits the world in 
a 'game world' and a 'real world' playing with the real world's frames, patterns and representations (Bateson 2000, 180). Similarly Dirk Baecker observes: "In play, socialness is constituted by ways of reflection of itself as the other side of itself. In play, socialness is experienced as what it is, namely as contingent, roughly meaning that it is neither necessary nor impossible, or again, given yet changeable" (Baecker 1999, 103). Today the logic of play is built into steering technologies in order to innovate, defreeze structures, potentialize responsibility, rethink reforms and much more (Andersen 2009, 2011; Knudsen and Andersen 2014; Andersen and Pors 2014a, 2014b).

Trust based partnerships are another example of potentialization technologies. Partnerships are contracts that desire to become communities. They are not simple agreements. In order to open up for flexible premises they are rather second order promises. Partnerships make promises about future promises. In this sense they both promise and do not promise to stay open and flexible. They promise to work together to explore the possibilities for future commitment (Andersen 2008b, 2012a). They function as fragile possibility machines potentializing collaborations, rather than as a simple machine of realizing a given opportunity of agreement (Andersen 2008b).

Playful commands are decisions that encourage potentialization as the general attitude of staff and institutions. In 2012, the municipality of Aalborg launched a so-called 'freedom charter'. The freedom charter encourages officials, local welfare managers and professionals to think innovatively, let ideas flow, get rid of bureaucracy, and find the courage to pursue what makes their work meaningful. As they say: "It is time to realize the full potential of the organization". The municipality says, "Free yourself" and expects the institutions to follow this command by disobeying the municipality in other matters.

Potentializing reforms are initiated by central government, but engage a multiplicity of partners, encouraging them to reform themselves by defining the goal and task of the reform throughout the 
process, in other words potentializing the reform in the reform process.. "New Nordic Schooling" launched by the Minister of Education in the spring of 2012 is an example. This reform did not present itself as a reform but as a revolutionary social movement (the Minister's words). And instead of a strategy, it was a 'manifest with dogmas'. Dogma four reads: "We will systematically explore and be open to change: We will be curious, proactive, innovative and willing to take risks to realize the potential of individuals. To change the world we need to discover that something could be different and be willing to change the way we work." (Ministry of Education 2014, 17).

\section{Conclusion}

Often organizations are observed as having a history while decisions are observed "as old as man" (Köksalan, Wallenius, and Zionts 2013, 87). By observing decisions not simply as an individual choice, but as a very particular social form of communication we open up the black box, making it possible to study the history of the form of decision. Instead of looking just at the history of structures we have tried to look at the history of the operation. Earlier studies have focused on discourses and institutions as the context and structural conditions of the public sector (Thomas and Davies, 2005; Lorenz, 2012; Yeatman, 1993, 1998). Our study shows the operative point from where these discourses are observed and evaluated as communicative relevant or irrelevant within the public sector. Following the form of decision as the communicative operation we are able to describe the autopoietic machine from which the public sector is produced. Our story has not simply shown an increase in the complexity of the structure of the public sector, but a number of very interesting folds of the form of decisions into itself. Folds that allow the public sector to operate with many temporalities simultaneously, to contain paradoxes and even contain almost antagonistic forms of decision operations such as administrative decisions that aim to absorb uncertainty, and 
potentialisation that systematically deconstructs decision premises, with the aim of creating more undetermined complexity as a resource of change.

We have tried to describe this semantically by observing how the public administrative decision is formed and transformed as an operation in a Danish setting from 1880 until today. We have examined: 1) how the difference is drawn between fixed and open contingency, thus aiming to absorb uncertainty; 2) how decisions connect recursively to earlier decisions, drawing a difference between decision premises and decision; 3) and finally how this is expressed semantically, particularly regarding the temporality of decision-making.

We have shown how the operation of decision over time is split into four forms and orders of decision-making and how the driver has been internally produced complexity and continuously new ways of articulating the problem of handling complexity. So 'the steps' (see figure 6) do not tell a story from simple to complex, but a story about how different modes of dealing with complexity are put on top of each other, pushing ever-new versions of decision paradoxes ahead of them.

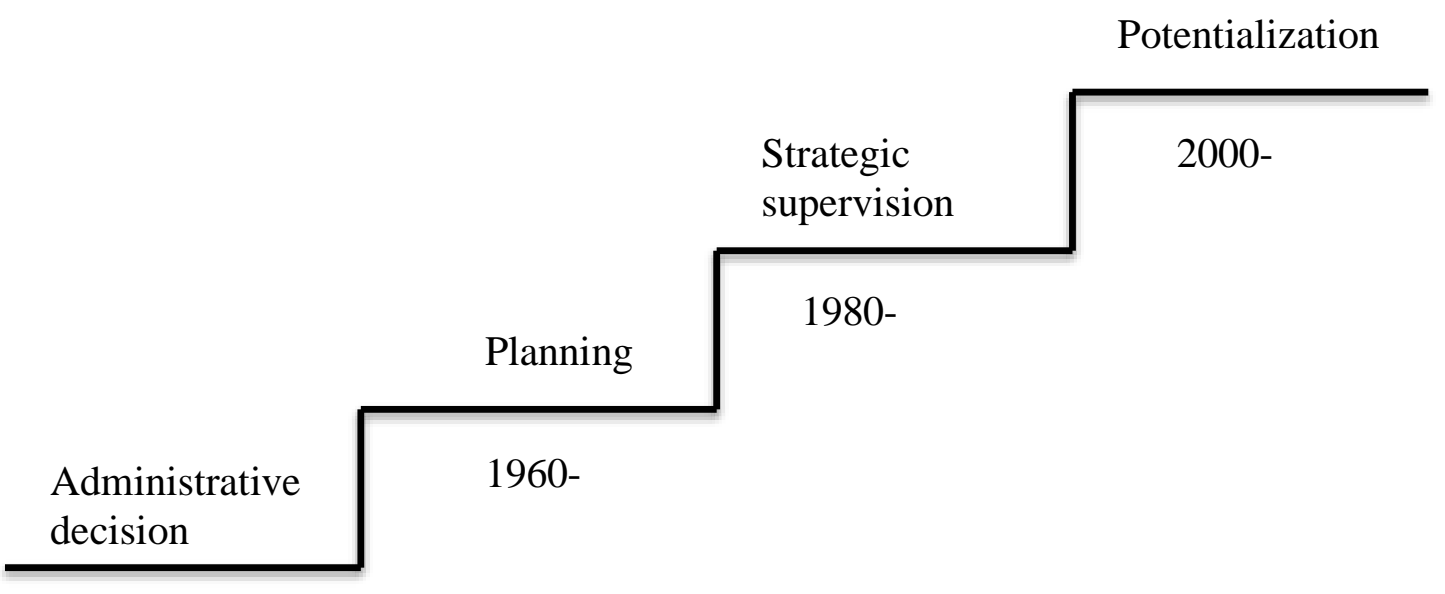

$1880-$

Figure 6: Orders of decision 
As we move up the ladder from decision of first order, to second, third and fourth, it becomes more difficult to assess whether a statement like "this is a decision" actually indicates what it indicates (this goes both for us as researchers and for the organization). At the first order an administrative decision is a unilateral statement about a case, attuning expectations by deciding on a specific option rather than certain alternative options. Planning as a second order decision is also a unilateral statement, but about problems and priority, thus serving as premises for later administrative decisions. Strategic supervision is not simply a unilateral statement, but a unilateral call for mutuality saying "Do as we say -Be autonomous". Strategic supervision creates premises for later organizational planning and management by fixing the horizon of future into which problems might be located. As a decision premise, strategic supervision is both a double bind and a withdrawal. Finally, potentialization emerges as a decision of a fourth order. Potentialization is a decision to generate new contingency and a new horizon of contingency. In this way, it represents a kind of anti-decision decision. Instead of trying to absorb uncertainty, potentialisation celebrates uncertainty as a limited resource. It commands, "Obey by not obeying decisions and structures" As we move up the ladder of orders of decisions the temporality of decision changes. First, the present past is observed as a premise of decision-making. Second, the observation of the future of the present brings the future into the present as a planning premise. Third, the observation of the present of the future, futurizes the present and opens a horizon of strategic possibilities. Finally, the split temporality of, on the one hand, singular moments of present present, and, on the other hand, a future of the future invites the organization to think the unthinkable and thus potentialise the moment. Of course the public administrative has not simply switched from one temporality to another. New temporalities are added and the result is a multiplicity of temporalities, which do not simply co-exist, but create quite important semantic frictions. To potentialization, structures are 
something to be chosen from moment to moment. To administrative decisions, structures are everything that constitute the possibility of a legal state.

All forms of public administration exist simultaneously and side by side, and sometimes it takes only a moment to oscillate from one form to another, and the world looks completely different. Imagine a municipality that experiments with radically altering its gaze for social clients, regarding them as infinite resources. Then the National Revision Unit choses to look into their practices and what they see are not potentialization, but highly problematic procedures that violate personal rights and administrative law. The reality of formal administration suddenly gets the last say. With the many layers, we do not simply have an administrative game, but a constant game about which game to play.

\begin{tabular}{|l|l|l|l|}
\hline & $\begin{array}{l}\text { Form of } \\
\text { decision }\end{array}$ & Orientation & Temporality \\
\hline $\begin{array}{l}\text { Potentiality } \\
\text { administration }\end{array}$ & Potentialization & $\begin{array}{l}\text { Indeterminate } \\
\text { complexity }\end{array}$ & $\begin{array}{l}\text { Future future and } \\
\text { present present }\end{array}$ \\
\hline $\begin{array}{l}\text { Supervision } \\
\text { administration }\end{array}$ & $\begin{array}{l}\text { Strategic } \\
\text { supervision }\end{array}$ & Future & Present future \\
\hline $\begin{array}{l}\text { Sector } \\
\text { administration }\end{array}$ & Planning & Problem & Future present \\
\hline Bureaucracy & $\begin{array}{l}\text { Administrative } \\
\text { decision }\end{array}$ & Case & Present past \\
\hline
\end{tabular}

Figure 7: The developments in the form of decision

As we move up the ladder of orders of decisions, it becomes increasingly difficult to create decision premises and observe something as premises at all (as illustrated in figure 7). At best they are an add-on after the decisions are made. What emerges seems to be a public administration that tries to protect its operation, even when it has to protect it against public administration itself. The public sector seems to protect its decision operation against its structure, which is particularly interesting bearing in mind that its operations are precisely about fixation of expectations to create (structural) premises for new decision operations. 
Concepts and ideas such as "radical innovation", "co-creation", "expect the unexpectable", "entrepreneurial spirit" "design thinking" and "public value" are not simply a fresh breeze of air after the dominance of NPM in the public sector. They indicate the new hegemonic discourse, and just as the problem of NPM was that it did a lot more than what it promised, the new spirit of potentialisation has larger and more severe effects than it agents are often aware of and might represent a much more cruel attack on legality and classical bureaucratic value that NPM did. Our reference has been the Danish public sector. In most western welfare states the first three layers (bureaucracy, sector administration, supervision administration) are observable, maybe with a span of institutional variation, and different 'balances' between the layers. The potentialisation layer is more questionable as an international phenomenon in the public sector. However, Denmark hardly ever invent something new, but is often quicker than most to take in new trends. And if you look around, potentialisation is also at the agenda in many other states, but maybe more fragmented and not so institutionalized. Just to give a single example, Australian Public Service Commission recently introduced the buzz word "unlocking potential" in their new policy program for public sector named: "Shape Australia. Create your future" (Easton 2017, Australian Public Service Commission 2015). An earlier Danish government talked about Denmark as a pioneer country. It might be important to look at what is happening with the Danish public sector right now. The imperative is here to fight for the life of the welfare state. Many radical experiments take place. Denmark might be pioneers, but maybe not for something entirely unproblematic.

\section{References}

Administrationsdepartementet (1980): Beretning 1980, Copenhagen.

Administrationsudvalget af 1960 (1962a): "1. betænkning", Betcenkning nr. 301, København. Administrationsudvalget af 1960 (1962b): "2. betænkning", Betcenkning nr. 320, København. 
Administrationsudvalget af 1960 (1963): "3. betænkning", Betæenkning nr. 342, København.

Administrationsudvalget af 1960 (1965): "4. betænkning", Betcenkning nr. 380, København.

Administrationsudvalget af 1960 (1966): "5. betænkning", Betcenkning nr. 408, København.

Andersen, Niels Åkerstrøm and Sand, Inger-Johanne (2012) (ed): Hybrid forms of governance. Selfsuspension of power, Palgrave Macmillan, London.

Andersen, Niels Åkerstrøm (1995): Selvskabt forvaltning, Forvaltningspolitikkens og centralforvaltningens udvikling i Danmark 1900-1994, Nyt fra Samfundsvidenskaberne, Frederiksberg.

Andersen, Niels Åkerstrøm (2003): Borgerens kontraktliggфrelse, Hans Reitzels Forlag, København.

Andersen, Niels Åkerstrøm (2005): ’Political Administration”, in David Howard and Jacob Torfing (ed) Discourse theory in European Politics: Identity, policy and governance, Palgrave Macmillan, New York.

Andersen, Niels Åkerstrøm (2007): "Creating the client who can create himself and his own fate the tragedy of the citizens' contract" in Qualitative Sociology Review, Vol III, Issue 2, pp. 119-143. Andersen, Niels Åkerstrøm (2008): Partnerships: Machines of Possibility, Policy Press, Bristol. Andersen, Niels Åkerstrøm (2009): Power at play. The relationships between play, work and governance, Palgrave Macmillan, London.

Andersen, Niels Åkerstrøm (2011a): "Conceptual history and the diagnostics of the present” in Management and Organizational History, Vol. 6(3): 248-267. 
Andersen, Niels Åkerstrøm (2011b): "Who is Yum-Yum? A cartoon state in the making”, in Ephimera, theory and politics in organization, Vol. 11(4): 406-432.

Andersen, Niels Åkerstrøm (2013): Managing intensity and play at work, Transient Relationships, Edward Elgar, Cheltenham, UK.

Andersen, Niels Åkerstrøm and Born, Asmund (2000): "Complexity and Change: Two "Semantic Tricks" in the Triumphant Oscillating Organization", in System Practice and Action Research, Vol. 13, No 3, pp. 297-328.

Andersen, Niels Åkerstrøm and Born, Asmund (2001): Karlighed og omstilling. Italesattelsen af den offentligt ansatte, Nyt fra samfundsvidenskaberne, Frederiksberg.

Andersen, Niels Åkerstrøm and Knudsen, Hanne (2014): “Playful Hyper Responsibility: toward a dislocation of parents' responsibility", in Journal of Education Policy, Vol. 29, no. 1, p. 105-129. DOI:10.1080/02680939.2013.791929.

Andersen, Niels Åkerstrøm and Pors, Justine Grønbæk (2014a): ’Playful membership: Embracing an unknown future" in Management and Organizational History, Vol. 9, Issue 2, pp.166-183, DOI:10.1080/17449359.2014.891796

Andersen, Niels Åkerstrøm and Pors, Justine Grønbæk (2014b): “Playful organisations:

Undecidability as a scarce resource", in Culture and Organization, DOI:

10.1080/14759551.2014.924936, Vol. 21, no. 4, pp. 338-354.

Andersen, Niels Åkerstrøm and Pors, Justine Grønbæk (2016): Public management in transition. The Orchestration of potentiality, Policy Press, Bristol. 
Andersen, Niels Åkerstrøm, (2012): “To promise a promise: When contractors desire a life-long partnership", in Niels Åkerstrøm Andersen and Inger-Johanne Sand, 2012 (ed): Hybrid forms of governance-Self-suspension of power, Palgrave Macmillan, London, p. 205-231.

Andersen, Poul (1924): Om ugyldige Forvaltningsakter med sarligt Henblik paa Ugyldighedsgrunde, Arnold Buscks Forlag, København.

Andersen, Poul (1926): ’Kontrakt eller forvaltningsakt?”, Nordisk Administrativt Tidsskrift, årg 17. 78-84.

Andersen, Poul (1943): ’Politik og forvaltning”, Nordisk Administrativt Tidsskrift, årg. 24, p. 174192

Arbejdsministeriet (1971): Perspektivplanlacgning 1970-1985, Copenhagen.

Arbejdsministeriet (1973): Perspektivplanlagning 1972-1987, Copenhagen.

Australian Public Service Commission (2015): Unlocking potential, (C) Commonwealth of Australia 2015.

Blaschke, Steffen, Schoeneborn, Dennis and Seidl, David (2012). Organizations as networks of communication episodes: Turning the network perspective inside out. Organization Studies, 33(7), 879-906.

Bogdanor, Vernon (2001): Civil Service Reform: A critique. The Political Quarterly, 72(3): 291299.

Campbell, David (2007): "Relational Contract and the Nature of Private Ordering: A Comment on Vincent-Jones" Indiana Journal of Global Studies, vol. 14, no. 2, 279-300. 
Campbell, John and Pedersen, Ove K. (2014): The national origins of policy ideas: Knowledge regimes in the United States, France, Germany, and Denmark, Princeton University Press, New Jersey.

Condren, Conal (2006): Argument and authority in Early Modern England: The presupposition of oaths and offices. Oxford: Oxford University Press.

Corby, Susan (1993). "How big a step is Next Steps? Industrial Relations Developments in the Civil Service executive agencies", Human Resource Management Journal, 4(2): 4-19

Costea, Bogdan,, Crump, Norman \& Holm, John (2006) Conceptual History and the interpretation of managerial ideologies. Management \& Organizational History, Vol. 1(2), p. 159-175.

Crozier, Michael (2007): "Recursive Governance: Contemporary Political communication and public policy.” Political communication, vol. 24, 1-18.

Cyert, Richard M. and March, James G. (1963): A behavioral theory of the firm, Prentice-Hall Inc. Englewood Cliffs, New Jersey.

Cyert, Richard M., Simon, Herbert A., Trow, Donald B. (1956): “Observation of a business Decision", The Journal of Business, Vol. 29, no. 4, pp. 237-248.

Easton Stephen (2017): New Commonwealth recruiting slogan: 'Shape Australia. Create your Future.' In The Mandarin, 2/3 2017, http://www.themandarin.com.au/76236-new-australian-publicservice-recruiting-slogan-shape-australia-create-your-future/ .

Esposito, Elena (2011): The Future of Futures: The Time of Money in Financing and Society, Edward Elgar, Cheltenham, UK. 
Esposito, Elena (2013): The structures of uncertainty: performativity and unpredictability in economic operations, Economy and Society, 42:1, pp. 102-129.

Esposito, Elena (2014): "Plans and the Future: Designing the Unpredictable". in Michael Shamiyeh, ed., Driving Desired Futures. Turning Design Thinking into Real Innovation. Basel: Birkhäuser, pp.100-108

du Gay, Paul (2008) ““Without Affection or Enthusiasm’ Problems of Involvement and Attachment in 'Responsive' Public Management”, Organization, Vol. 15(3): 335-353.

du Gay, Paul (2009) "In defense of Mandarins: Recovering the 'core business' of public management", Management \& Organizational History, Vol. 4(4), pp. 359-384.

Finansministeriet (1983): "Redegørelse af 30/11 83 om regeringens program for modernisering af den offentlige sektor”, Redegørelse nr. R 4, Folketingstidende, sp. 2379-2392.

Freedland, Mark (1994): “Government by contract and public law”, Public Law (Spring): 86-104.

Greve, Carsten (2006): "Public management reform in Denmark", Public management review, Vol. 8, no. 1 , pp. $161-169$.

Henkel, Anna (2013): "Geneaology of the Pharmacon: new conditions for the social management of the extraordinary", Management and Organizational History, Vol. 8(3), pp. 262-276.

Holck, Carl, G. (1870): Den danske statsforvaltningsret, Forlaget af den Gyldendalske Boghandel, København.

Jensen, Lotte (2003): Den store koordinator, Jurist og Økonomforbundets Forlag, Copenhagen.

Jensen, Lotte (2008): Vak fra afgrunden, Syddansk Universitetsforlag, Odense. 
Jensen, Lotte (2012): "The self-suspension of Government", in Niels Åkerstrøm Andersen and Inger Johanne Sand (ed): Hybrid forms of governance - Self-suspension of power, Palgrave Macmillan, London.

Knudsen, Morten (2005): "Displacing the paradox of decision making”, in Seidl, David and Becker, Kai Helge (ed): Niklas Luhmann and organization studies, Liber and Copenhagen Business School Press, Copenhagen, pp. 107-126.

Kooiman, J. and Jentoft, S. (2009): "Meta-governance: Values, norms and principles, and the making of hard choices", Public Administration, Vol. 87(4), pp. 818-836.

Kooiman, Jan (2003): Governing as Governance, Sage, London.

Kooiman, Jan (2008): "Exploring the concept of Governability". Journal of Comparative Policy Analysis: Research and Practice, vol. 10, no. 2, s. 171-190.

Kooiman, Jan and Vliet, Martijn van (2000): "Self-governance as a mode of societal governance." Public Management, vol. 2, issue 3, 359-377.

Köksalan, Murat, Wallenius, Jyrki and Stanley Zionts (2013): “An early history of multiple criteria decision making”, Journal of multi-criteria decision analysis, Vol. 20, pp. 87-94.

Lindblom, Charles E. (1959): “The science of 'Mudling Through"”, Public Administrative Review, Vol. 59, p. 79-80.

Lorenz, Chris (2012) 'If You're So Smart, Why Are You under Surveillance? Universities, Neoliberalism, and New Public Management”, in Critical Inquiry, vol. 38: 559-629 
Luhmann, Niklas (1964): Funktionen und Folgen formaler Organisation, Duncker andHumblot, Berlin.

Luhmann, Niklas (1982): “The future cannot begin” in The differentiation of society, Columbia University Press, pp. 271-288.

Luhmann, Niklas (1990): “The autopoiesis of social systems”, in Niklas Luhmann (ed): Essays on self-reference, Columbia University Press, New York.

Luhmann, Niklas (1993): “Die Paradoxie des Entscheidens" i Verwaltungs-Archiv. Zeitschrift für Verwaltungslehre, Verwaltungsrecht und Verwaltungspolitik, 84. Band, heft 3, pp. 287-299.

Luhmann, Niklas (1995): Social systems, Stanford University Press, Stanford, California.

Luhmann, Niklas (2000): Organisation und Entscheidung. Wiesbaden: Westdeutscher Verlag.

Luhmann, Niklas (2013): Introduction to systems theory, Polity Press, Cambridge.

Mommsen, Wolfgang J. (1974): The age of bureaucracy, Basil Blackwell, Oxford.

Nassehi, Armin (2005): “Organizations as decision machines: Niklas Luhmann's theory of organized", in The sociological Review, vol. 53, November, pp. 178-191.

Planinformationsudvalget (1983): Al den planlagning - hvordan og hvorfor?, Planredegørelse 3, Finansministeriets, København.

Pors, Justine Grønbæk (2011): Noisy management: A history of Danish school Governing from 19702010, PhD Series; 24.2011, Copenhagen Business School, Frederiksberg. 
Pors, Justine Grønbæk (2012): "Avoiding Unambiguity: Tension in school governing" in Niels Åkerstrøm Andersen and Inger Johanne Sand (ed): Hybrid forms of governance - Self-suspension of power, Palgrave Macmillan, London.

Regeringen (2006): På vej mod en kvalitetsreform - debatpjece om udfordringerne, Finansministeriet.

Regeringen (2007): ’Nytænkning og konkurrence. En innovativ offentlig sektor, der giver mere kvalitet til borgerne og bedre arbejdspladser for medarbejderne”, Regeringens debatoplæg til møde om kvalitetsreformen, Finansministeriet.

Rennison, Bettina (2007): "Historical Discourses of Public Management in Denmark: Past Emergence and Present Challenge.” Management and Organisational History, Vol. 2 (1): 2-26.

Ross, Alf (1959): Statsretlige studier, Nyt Nordisk Forlag Arnold Busck, København.

Simon, Herbert (1959): “Theories of decision-making in economics and behavioral science", The American Economic Review, Vol. XLIX, June, No. 3, pp. 253-283.

Simon, Herbert (1961): Administrative behavior. A study of decision-making in administrative organization, Second edition, The Macmillan Company, New York.

Simon, Herbert (1964): “On the concept of organizational goal”, Administrative Science Quarterly, Vol. 9, No. 1, pp. 1-22.

Schoeneborn, Dennis, Blaschke, Steffen, Cooren, Francois, McPhee, Robert D., Seidl, David., and Taylor, James R. (2014). The three schools of CCO thinking: Interactive dialogue and systematic comparison. Management Communication Quarterly, 28(2), 285-316.

Spencer Brown, George (1969). Laws of form. London: Allen \& Unwin. 
Stäheli, Urs. 2003. "Financial Noises: Inclusion and the Promise of Meaning.” Soziale Systeme, Vol. 9 (2): 244-256.

Teknikerkommissionen (1959): "Teknisk og naturvidenskabelig arbejdskraft", Betcenkning nr. 229, København.

Thomas, Robyn and Davies, Annette (2005): Theorizing the Micro-politics of Resistance: New Public Management and Managerial Identities in the UK Public Services, Organization Studiesisepép 26(5): 683706.

Thygesen, Inge (1980): “Flerniveau-planlægning af det offentliges udgiftspolitik”, Indlarg på Nationalфkonomisk Forenings konference om фkonomisk planlagning, 3/9, Copenhagen.

Udvalget vedr. Centraladministrationens planlægningsvirksomhed (1975): "Planlægning i centraladministrationen”, Betcenkning nr. 743, København.

Ussing, Johannes (1893): Om afgфrelser af tvistigheder med forvaltningen, Sarlig om administrative retter, PG. Phillipsens Forlag, København.

Vincent-Jones, Peter (2007): “The new Public Contracting: Public Versus Private Ordering?” Indiana Journal of Global Legal Studies, vol. 14, no. 2, 259-278.

Vincent-Jones, Peter, Hughes, David and Mullen, Caroline (2009): “New Labour's PPI Reforms: Patient and Public Involvement in Healthcare Governance?" The Modern Law Review, vol. 72, no. 2, 247-271.

Weber, Max (1978): Economy and society, vol. 2., University of Califonia Press, London. 
Willke, Helmut (1992): Ironie des Staates, Suhrkamp, Frankfurt am Main.

Willke, Helmut (1997): Supervision des Staates, Suhrkamp, Frankfurt am Main.

Yeatman, A. (1993). "Corporate managerialism and the shift from the welfare to the competition state.” The Australian Journal of Education Studies, 13(2), 3-9.

Yeatman, A. (1998). Trends and opportunities in the public sector: a critical assessment. Australian Journal of Public Administration, 57(4), 138-147. 